\title{
Tumor pardo maxilar: Elemento diagnóstico de hiperparatiroidismo primario
}

\author{
Maxillary brown tumor: A diagnostic tool for primary hyperparathyroidism
}

\author{
S. Gallana Álvarez', C.I. Salazar Fernandez², F.J. Avellá Vecino33, \\ J. Torres Gómez4, J.M. Pérez Sanchez ${ }^{5}$
}

Resumen: El hiperparatiroidismo primario es un transtorno generalizado del metabolismo óseo producido por un aumento de la secreción de hormona paratiroidea (PTH).

La etiología de este transtorno es múltiple; en la forma primaria la causa de la hipersecreción de la hormona es la propia glándula, y el motivo más frecuente el adenoma paratiroideo. Los tumores pardos son lesiones óseas focales secundarias a hiperparatiroidismo

El tratamiento de elección de los tumores pardos es la extirpación del adenoma de paratiroides, ya que la normalización de la función paratiroidea debería provocar una reducción del tamaño o desaparición del tumor.

Presentamos un caso de tumor pardo mandibular en un paciente con hiperparatiroidismo primario, en el cual el tumor recidivó después de la extirpación del adenoma paratiroideo.

La finalidad de la presentación de este caso es recordar el interés que para el cirujano oral y maxilofacial representan las manifestaciones orales de la patología sistémica.

Palabras clave: Hiperparatiroidismo; Tumor pardo; Maxila.

Recibido: 13 de diciembre de 2004

Aceptado: 25 de mayo de 2005
Abstract: The primary hyperparathyroidism is a generalized disorder of the osseous metabolism, caused by hypersecretion of PTH.

Hyperparathyroidism has a multiple etiology. In its primary form, the hypersecretion of the hormone is caused by the gland itself, the commonest reason being parathyroid adenoma.

The treatment of first choice for brown tumor is the parathyroidectomy because the normalization of parathyroid function should lead to a reduction in size or disappearance of the tumor.

We present a case of the brown tumor in the mandible and primary hyperparathyroidism in whom the tumor enlarged after removal of parathyroid adenoma.

Upon presentation of this report, our aim is to bring forward the significance oral manifestations of systemic pathology has for oral and maxillofacial surgeons.

Key words: Hyperparathyroidism; Brown tumor; Maxilla.

\footnotetext{
1 Médico residente. Servicio de Cirugía Oral y Maxilofacial.

2 Médico adjunto. Servicio de Cirugía Oral y Maxilofacial.

3 Médico especialista de Cirugía Oral y Maxilofacial.

4 Médico especialista de Anatomía Patológica.

5 Jefe de Servicio. Servicio de Cirugía Oral y Maxilofacial.

Hospital Universitario Virgen Macarena. Sevilla. España.
}

\section{Correspondencia:}

Silvia Gallana Alvarez.

c/ Isbilia №10

41907 Valencina de la Concepción. Sevilla, España.

E-mail: sgallana@hotmail.com 


\section{Introducción}

Se define el hiperparatiroidismo como aquel estado metabólico en el que se produce un aumento en la secreción de hormona paratiroidea (PTH). La función fundamental de esta hormona es el control del metabolismo del calcio. ${ }^{1}$

La hipersecreción de PTH se caracteriza por una hipercalcemia, hipofosfatemia y metabolismo óseo anormal. La hipercalcemia constituye la clave para el diagnóstico de esta enfermedad, siendo el dato metabólico más importante. ${ }^{2}$

La etiología del hiperparatiroidismo es múltiple; la forma primaria suele deberse a un tumor benigno funcionante (adenoma paratiroideo) de alguna de las cuatro glándulas paratiroides, que produce hormona en exceso. ${ }^{3}$

La afección ósea del hiperparatiroidismo es la Osteítis Fibrosa Quística, descrita por primera vez en 1891 por Von Recklinghausen. Dentro de las manifestaciones de esta enfermedad, los tumores pardos representan un ejemplo de lesión focal.2,5,6

Estos tumores pardos se consideran una lesión reparativa de células gigantes, y se observan como una lesión osteolítica, por lo general multilocular, bien delimitada y con adelgazamiento de las corticales óseas. ${ }^{2,4}$ En estos casos es importante el diagnóstico diferencial con otras lesiones de células gigantes que afectan a los maxilares.

Los tumores pardos pueden aparecer en cualquier parte del esqueleto, y cuando aparecen en cabeza y cuello, afectan generalmente a la mandíbula, a este nivel encontramos una disminución de la densidad radiográfica, una desmineralización del reborde inferior mandibular y del conducto dentario inferior, así como un adelgazamiento de los contornos corticales de los senos maxilares.7,8 También se han descrito tumores pardos en otras áreas del macizo facial incluída la región orbitaria. 9,10

Mientras la mayoría de los autores están de acuerdo en que el tratamiento inicial del hiperparatiroidismo primario debe ser la extirpación de la glándula paratiroidea enferma, causando una regresión de las lesiones óseas, otros han combinado la paratiroidectomía con el curetaje y enucleación de las lesiones mandibulares.9,11,12

A pesar de que actualmente con las técnicas analíticas disponibles, los pacientes con hiperparatiroidismo suelen ser diagnosticados en una fase temprana de la enfermedad antes de que aparezcan lesiones óseas, debemos tener en cuenta la posibilidad de encontrarnos con diagnósticos tardíos y afectaciones óseas extensas. 9,13

\section{Caso clínico}

Varón de 31 años de edad, con antecedentes personales de cefaleas tensionales, astenia en los últimos meses y úlcera gástrica. Es remitido a nuestra consulta por su odontólogo en junio del 2000, por presentar episodios repetidos de inflamación en maxilar inferior derecho e imagen radiográfica radiotransparente en ángulo mandibular derecho, en la vecindad de las piezas 47 y 48 . La exploración radiológica realizada en nuestra consulta (ortopantomografía), detecta una lesión de aspecto quístico, osteolítica, multilocu-

\section{Introduction}

Hyperparathyroidism has been defined as a metabolic condition that produces an increase in the secretion of the parathyroid hormone (PTH). The basic function of this hormone is the metabolic control of calcium. ${ }^{1}$

The hypersecretion of PTH is characterized by hypercalcemia, hypophosphatemia and abnormal bone metabolism. Hypercalcemia is the key for diagnosing this disease and it represents the most important metabolic feature. ${ }^{2}$

The etiology of hyperparathyroidism is multiple; the primary form is normally due o a benign functioning tumor (parathyroid adenoma) of one of the four parathyroid glands, that produces excess hormone. ${ }^{3}$

Bone disorder by hyperparathyroidism is called Osteitis Fibrosa Cystica and it was first described in 1891 by Von Recklinghausen. Of the manifestations of this disease, brown tumors represent an example of a focal lesion. 2,5,6

Brown tumors are considered a reparative lesion of giant cells, and their appearance is of an osteolytic lesion, that is generally multilocular, well-defined and with thinning of cortical bone. ${ }^{2,4}$ In these cases the differential diagnosis is important and it should include other giant cell lesions that affect the maxillae.

Brown tumors can appear in any part of the skeleton and when they appear in the head and neck they generally affect the mandible. Here we generally find a reduction in radiographic density, demineralization of the lower mandibular border and of the lower dental arch, as well as a thinning of the cortical rims of the maxillary sinuses.7,8 Brown tumors have also been described in other areas of the face including the orbital region. 9,10

While most authors agree that the initial treatment for primary hyperparathyroidism should be the removal of the diseased parathyroid gland, causing the regression of bone lesions, others have combined a parathyroidectomy with curettage and an enucleation of mandibular lesions. 9,11,12 Despite the current analytical techniques available, and that patients with parathyroidism tend to be diagnosed at an early stage of the disease before the appearance of bone lesions, we should bear in mind the possibility of coming across late diagnoses with extensive bone involvement.9,13

\section{Clinical case}

A 31-year-old male, with a medical history of tension headaches, over the previous months and a gastric ulcer was referred to our Service by his dentist in June 2000, as he had repeated episodes of inflammation of the lower right maxilla and a radiotransparent $x$-ray image of the right mandibular angle in the areas of teeth numbers 47 and 48 . The radiological examination carried out by our Service (orthopantomography) detected a cystic lesion that was osteolytic and multilocular, with clear well-defined borders and located in the lower maxilla. It was affecting teeth numbers 47 and 48 (Fig. 1). 
lar, de bordes nítidos y bien definidos, localizada en maxilar inferior relacionada con las piezas 47 y 48 (Fig. 1).

Se realiza biopsia de la lesión obteniendo el resultado de granuloma reparativo de células gigantes. Posteriormente en julio del 2000 se realiza tratamiento quirúrgico de la lesión mediante legrado y relleno óseo.

El estudio anatomopatológico de la lesión la describe cómo un estroma fibroblástico denso, donde se encuentran distribuidas numerosas células gigantes, con áreas hemorrágicas, acompañadas de macrófagos con pigmento hemosiderínico, estableciendo el diagnóstico de granuloma reparador de células gigantes (Fig. 2).

Dada la naturaleza de la lesión, se solicita perfil analítico del metabolismo fosfocálcico, descubriendo en la analítica, un nivel de PTH de $101 \mathrm{mg} / \mathrm{dl}$ (n:10-65), Calcio $11 \mathrm{mg} / \mathrm{dl}(\mathrm{n}: 8,5-10,5)$ y Fósforo $2,3 \mathrm{mg} / \mathrm{dl}(\mathrm{n}: 2,5-4,5)$. Por ello, se establece el diagnóstico de tumor pardo e hiperparatiroidismo y se envía al servicio de endocrinología en enero del 2001 para su valoración. Allí se solicita estudio de la función tiroidea, ecografía de tiroides-paratiroides, así como gammagrafía de paratiroides. El estudio de la función tiroidea es normal. El estudio de imagen

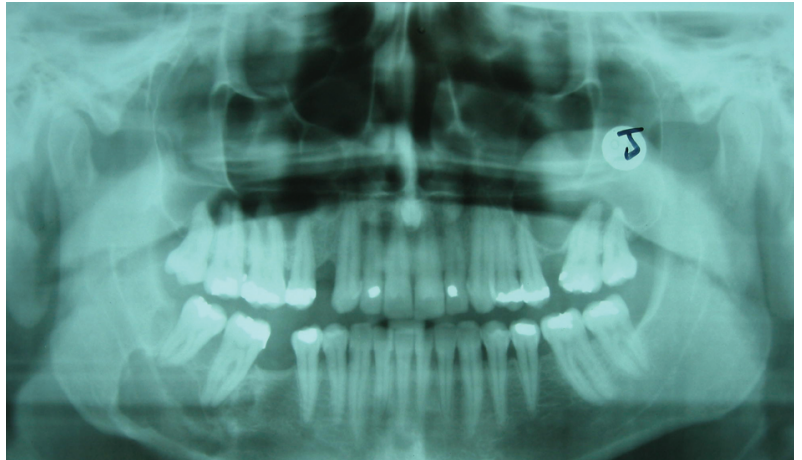

Figura 1. La OPG inicial, muestra una lesión de aspecto quístico y multilocular relacionada con 46 y 47.

Figure 1. Initial OPG showing a multilocular lesion with a cystic appearance with involvement of 46 and 47 teeth.

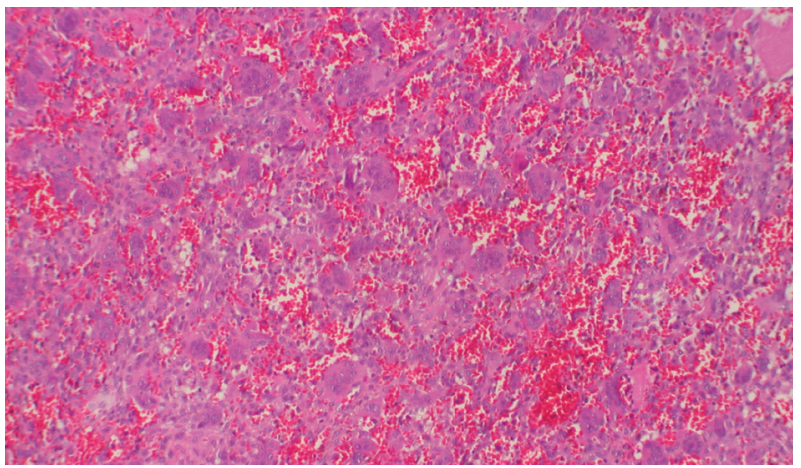

Figura 2. Sección histológica dónde aparecen numerosas células gigantes con áreas hemorrágicas.

Figure 2. Histologic section showing numerous giant cells with hemorrhagic areas.
A biopsy was carried out of the lesion and the result was of a reparative granuloma of giant cells. Later, in July 2000 , surgical treatment was carried out on the lesion by means of curettage and bone fill.

The anatomopathologic study of the lesion described it as a dense fibroblastic stroma, containing numerous giant cells that had hemorrhagic areas, with macrophages with hemosiderin pigment, that established the diagnosis of reparative granuloma of giant cells (Fig. 2).

Given the nature of the lesion, an analytical profile of the phosphocalcic metabolism was requested and by means of the tests a PTH level was discovered of $101 \mathrm{mg} / \mathrm{dl}$ ( $\mathrm{n}$ : 10-65), Calcium $11 \mathrm{mg} / \mathrm{dl}$ ( $\mathrm{n}$ : 8.5-10.5) and phosphate 2.3 $\mathrm{mg} / \mathrm{dl}$ ( $\mathrm{n}: 2.5-4.5$ ). As a result of this, the diagnosis was established of brown tumor with hyperparathyroidism and he was sent to the Endocrinology Service in January 2001 for evaluation. A thyroid funcde lesión, ni de aumento de tamaño de las glándulas paratiroideas. Los resultados de la gammagrafía tiroidea demuestran la presencia de un adenoma de paratiroides en glándula inferior derecha (Fig. 3). Con este diagnóstico se envía al servicio de Cirugía general para su extirpación quirúrgica.

Mientras el paciente se encuentra en espera de dicho tratamiento quirúrgico, es controlado periódicamente en nuestra consulta, observando una correcta osificación a nivel mandibular (Fig. 4).

En febrero de 2003 es intervenido de su lesión paratiroidea; tras la extirpación del adenoma de paratiroides, continuamos controles evolutivos encontrando a nivel mandibular una recidiva de la lesión (Fig. 5) por lo que se decidió realizar una nueva extirpación quirúrgica, en octubre de 2004.

Actualmente aunque el periodo de seguimiento es corto ha presentado una buena evolución postquirúrgica.

\section{Discusión}

La incidencia del hiperparatiroidismo primario oscila alrededor del $0,1 \%$. Es de dos a tres veces más frecuente en el sexo femenino y se observa sobre todo entre la $3^{\underline{a}}$ y la $6^{\underline{a}}$ década de la vida. ${ }^{3,4}$ tion test was requested together with a thyroid/parathyroid ultrasound as well as a gammagraphy of the parathyroid glands. The thyroid function test was normal. The imaging test by means of ultrasound did not show any lesion, nor an increase in the size of the parathyroid glands. The results of the thyroid gammagraphy showed a parathyroid adenoma in the lower right gland (Fig. 3). With this diagnosis he was sent to the General Surgery Service for its surgical removal.

While the patient was waiting for surgical treatment, he was monitored periodically in our unit, and correct ossification in his jaw was observed (Fig. 4).

In February 2003 the parathyroid lesion was operated on. After the removal of the parathyroid adenoma, his progress was monitored and a mandibular recurrence of the lesion was discovered (Fig. 5) and a decision was taken to excise this again surgically in October 2004. Although the followup period is short, his progress postsurgery has been good.

\section{Discussion}

The incidence of primary hyperparathyroidism is around $0.1 \%$. It is between two and three times more common in 
La causa más frecuente de hiperparatiroidismo primario es el adenoma paratiroideo (81\%), seguido por la hiperplasia glandular (15\%); el carcinoma paratiroideo aparece sólo en el 0,4-0,5\% de los casos. ${ }^{9}$

Las manifestaciones clínicas de la enfermedad cubren un rango bastante amplio, pero la mayoría de los pacientes presentan síntomas y signos debidos a cálculos renales, úlcera péptica, problemas psiquiátricos y dolores óseos y articulares. En nuestro caso, el paciente presentó antecedentes de astenia y úlcera gástrica. Sin embargo, autores cómo Suarez-Cunqueiro, ${ }^{7}$ y Udelsman, ${ }^{14}$ presentan casos en los que los pacientes eran asintomáticos al diagnóstico.

La incidencia de las lesiones óseas en el entorno del hiperparatiroidismo ha disminuido desde el $80 \%$ hasta el $15 \%$ en nuestros días, ${ }^{2}$ disminución que es atribuible al mejor control de la hipercalcemia en pacientes asintomáticos y a la generalización de los estudios bioquímicos. A pesar de ello Dilip y cols., ${ }^{5}$ revelan en una serie de 40 casos, afectación ósea generalizada en todos ellos.

Dentro de las manifestaciones óseas del hiperparatiroidismo se encuentran los tumores pardos, que se producen aproximadamente en el $10 \%$ de los casos y en fases avanzadas de la enfermedad. ${ }^{15,16}$ Éstos pueden aparecer en cualquier parte del esqueleto, pero son más frecuentes en costillas, clavícula y pelvis. La afectación mandibular ha sido registrada en el 4,5\% de pacientes. ${ }^{7}$ Debido al efecto directo de la PTH sobre el hueso, se produce la conversión del potencial osteogénico de las células, desde osteoblastos a osteoclastos, predominando entonces la resorción ósea sobre la formación de nuevo tejido óseo. Se elabora de este modo un tejido osteoide dentro de un tejido fibroblástico vascular, en un fracasado intento de formación de trabéculas óseas. ${ }^{5}$ Cómo resultado del sangrado intraóseo y de la degeneración tisular pueden desarrollarse quistes; grupos de macrófagos cargados de hemosiderina, células gigantes y fibroblastos llenan estas lesiones quísticas. La vascularización, hemorragias y los depósitos de hemosiderina confieren las características pardas de las lesiones y le dan el nombre de tumores pardos. ${ }^{5,17}$

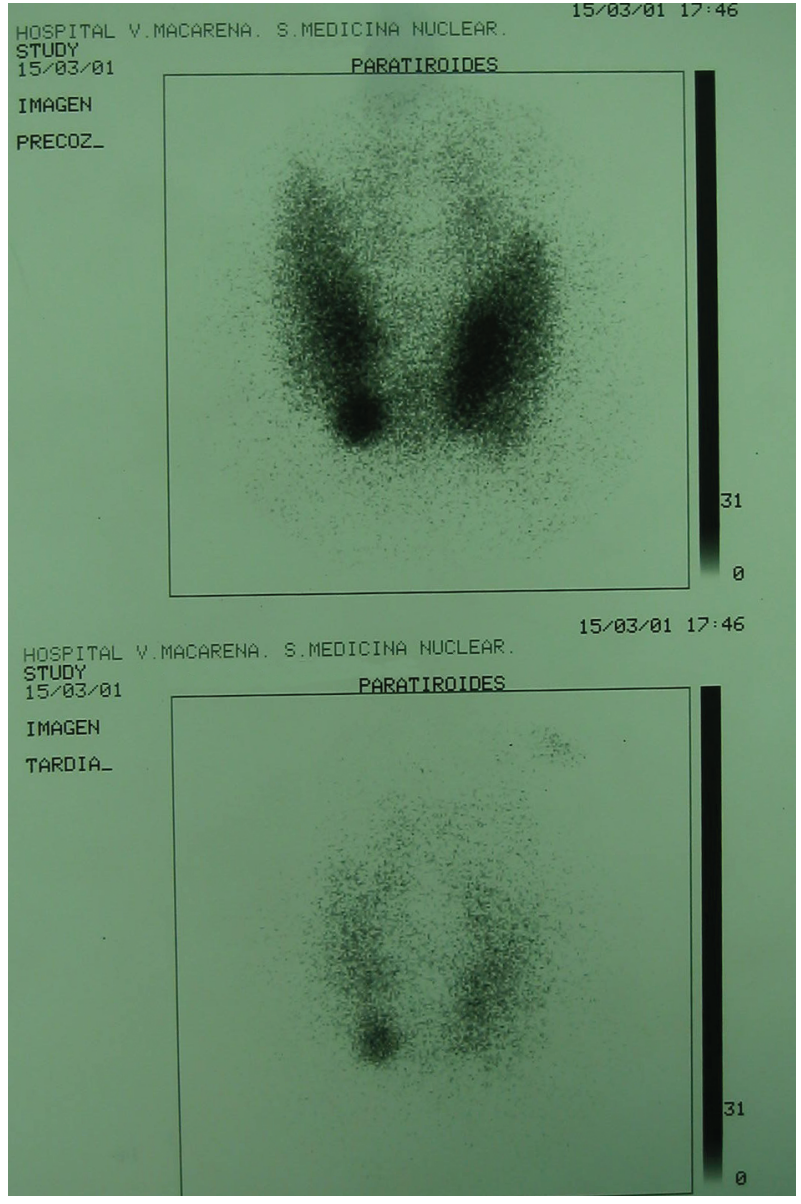

Figura 3. Gammagrafía tiroidea, se aprecia un aumento de captación a nivel de glándula paratiroidea inferior derecha.

Figure 3. Gammagraphy of the thyroid where an increase in the up take level of the lower right parathyroid gland can be appreciated.

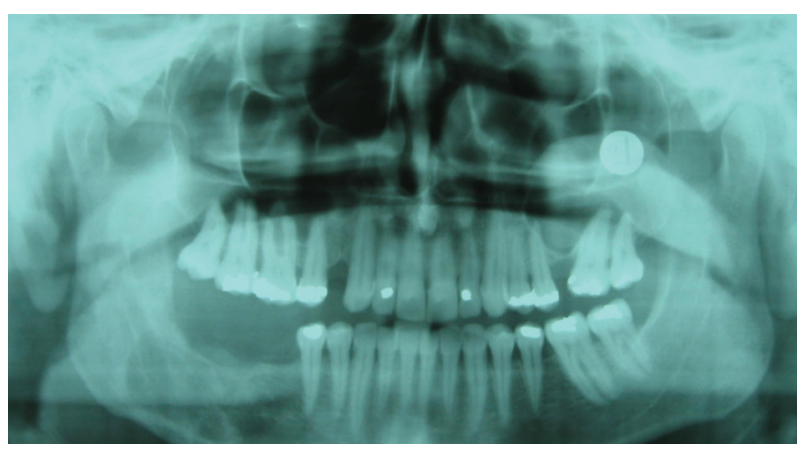

Figura 4. OPG de control, donde se observa una correcta osificación.

Figure 4. Monitoring with $O P G$, showing correct ossification. the female sex and it is observed particularly in the $3^{\text {rd }}$ and $6^{\text {th }}$ decades in life. ${ }^{3,4}$ The most common cause of primary hyperparathyroidism is parathyroid adenoma (81\%), followed by glandular hyperplasia (15\%), with parathyroid carcinoma appearing only in 0.4-0.5\% of cases. ${ }^{9}$

The clinical manifestations of the disease cover a fairly wide range, but most patients present signs and symptoms as a result of renal stones, peptic ulcers, psychiatric problems and pain associated with bones and joints. In our case, the patient had a background of asthenia and a gastric ulcer. However, authors such as Suarez-Cunqueiro ${ }^{7}$ and Udelsman ${ }^{14}$ report cases of patients that were asymptomatic at diagnosis.

The incidence of bone lesions with regard to hyperparathyroidism has fallen from $80 \%$ to a current $15 \%,{ }^{2}$ a reduction that is attributed to better hypercalcemia monitoring in patients that are asymptomatic and to biochemical studies becoming generalized. In spite of this, Dilip and cols., 5 reported a series of 40 cases that all had generalized bone involvement.

Within the osseous manifestations of hyperparathyroidism there are brown tumors that appear in approximately in 10\% of cases and in advanced stages of the disease. ${ }^{15,16}$ They can appear in any part of the skeleton but it is more common for them to appear on the ribs, clavicle and pelvis. Mandibular involvement has been registered in $4.5 \%$ of patients. ${ }^{7}$ As a result of the direct effect of the PTH on bones, a conversion occurs of the osteogenic potential of the cells, turning them from osteoblasts 
Es preciso señalar que los tumores pardos son lesiones no neoplásicas que guardan gran similitud con los tumores de células gigantes, pero en el contexto del hiperparatiroidismo se consideran granulomas reparadores y no tienen el potencial maligno ni neoplásico de las verdaderas lesiones de células gigantes. ${ }^{18,19}$

La sintomatología causada por estas lesiones depende de su tamaño y localización. En la mandíbula pueden causar dolor o deformidad, así como alteraciones en la masticación, como le ocurrió

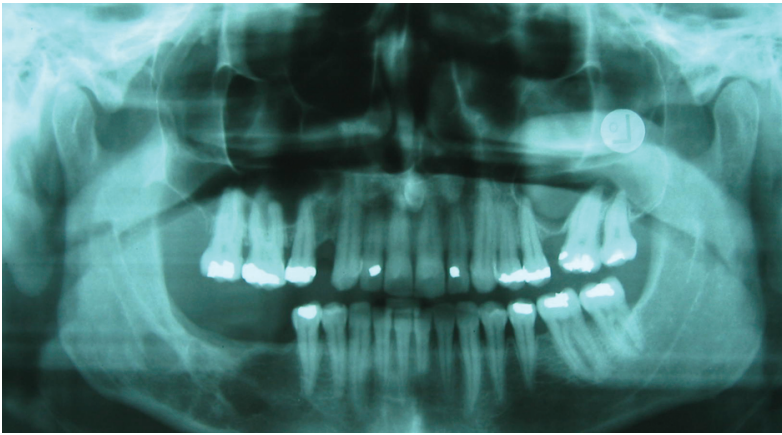

Figura 5. OPG de octubre del 2004. Aparece recidiva de la lesión. Figure 5. OPG in October 2004 showing a recurrence of the lesion. al caso clínico presentado. En otros casos, cómo el que presenta Fdez-Bustillo y cols. ${ }^{2}$ la lesión era asintomática, siendo el diagnóstico casual al realizar la exploración radiológica.

Ante una tumoración mandibular diagnosticada como lesión de células gigantes, se debe descartar analíticamente que exista un hiperparatiroidismo, estaríamos entonces ante un tumor pardo. Otros diagnósticos diferenciales incluyen el granuloma reparativo de células gigantes, el tumor de células gigantes, la displasia fibrosa y el quiste óseo aneurismático. El diagnóstico definitivo sólo es posible si comparamos los hallazgos clínicos, radiológicos y analíticos. ${ }^{11}$

Existe acuerdo en que el tratamiento de elección del hiperparatiroidismo primario es la paratiroidectomía, sin embargo las opiniones están divididas en cuanto al tratamiento de las lesiones óseas. Autores como Scott y cols., ${ }^{12}$ piensan que las lesiones óseas regresan espontáneamente tras la extirpación de la glándula paratiroidea enferma; otros como Martínez-Gavidia y cols., ${ }^{20}$ recomiendan tratamiento inicial con corticoides sistémicos para reducir el tamaño, seguido de extirpación quirúrgica de la lesión residual. En cualquier caso cuando se producen quistes extensos con gran destrucción, la cantidad de tejido dañado puede ser tan grande que existen pocas posibilidades de remodelación una vez instaurada la normocalcemia. ${ }^{7}$ En estas situaciones y en aquellos casos en los que las lesiones persisten más allá de seis meses, interfieren en la función del órgano afectado o incluso crecen a pesar de un control metabólico adecuado, Daniels y cols., ${ }^{9}$ y Yamazaki y cols. ${ }^{11}$ indican el curetaje y enucleación de las mismas. En nuestro caso debido a que la lesión recidivó 7 meses después a pesar de la paratiroidectomía, se decidió realizar tratamiento quirúrgico (enucleación y curetaje), de la misma en octubre del 2004 encontrándose actualmente asintomático.

\section{Conclusiones}

1. Actualmente gracias a la mejora de las técnicas analíticas, el diagnóstico de hiperparatiroidismo se realiza en una fase asintomática de la enfermedad, aunque aún existe la posibilidad de encontrar pacientes con lesiones óseas avanzadas.

2. En todas las lesiones de células gigantes se debería descartar la existencia de un hiperparatiroidismo primario. to osteoclasts, with bone resorption predominating over the formation of new bone tissue. In this way an osteoid tissue is formed within fibroblastic vascular tissue, in a failed attempt at forming bone trabeculae. ${ }^{5}$ As a result of intraosseous bleeding and of tissue degeneration, cysts may develop; groups of hemosiderin-loaded macrophages, giant cells and fibroblast fill these cystic lesions. Vascularization, hemorrhages and hemosiderin deposits give the brown characteristics of the lesions and the term brown tumors. ${ }^{5,7}$

It is important to point out that brown tumors are non-neoplastic lesions and that they are very similar to giant cell tumors, but in the context of hyperparathyroidism they are considered reparative granulomas and they do not have the malignant or neoplastic potential of real giant cell lesions. 18,19 The symptomatology caused by these lesions depends on their size and location. In the mandible they can cause pain or deformity, as well as alterations in mastication, as occurred in the clinical case presented. In other cases, such as the one presented by Fdez.-Bustillo and cols., ${ }^{2}$ the lesion was asymptomatic and the diagnosis was accidental as a result of a radiological examination.

When a tumor of the mandible has been diagnosed as a giant cell tumor, hyperparathyroidism should be ruled out by means of tests otherwise we could be before a brown tumor. Other differential diagnoses include the reparative granuloma of giant cells, giant cell tumors, fibrous displasia and aneurismatic bone cyst. The definitive diagnosis is only possible if the clinical, radiological and analytical findings are compared. ${ }^{11}$

There is agreement as to the treatment of choice for primary hyperparathyroidism being a parathyroidectomy, however opinions are divided as to the treatment for bone lesions. Authors such as Scott and cols., ${ }^{12}$ believe that bone lesions reappear spontaneously following removal of the diseased parathyroid gland; Others such as Mtnez-Gavidia and cols., ${ }^{20}$ recommend initial treatment with systemic corticoids in order to reduce the size, followed by surgical removal of the residual lesion. In any case, where there are large destructive cysts, the amount of tissue damaged may be so large that there are few possibilities of remodeling once normocalcemia has been acieved. ${ }^{7}$ In these situations, and when the lesions continue for more that six months, and there is interference with the affected organ, or there is even growth despite adequate metabolic control, Daniels and cols., ${ }^{9}$ and Yamazaki and cols., 11 recommend curettage and enucleation. In our case due to the lesion recurring seven months later in spite 
3. El tratamiento de primera elección de las lesiones óseas es la paratiroidectomía; sin embargo, en lesiones de mayor tamaño, en aquellas en las que persista el crecimiento a pesar de dicho tratamiento o en lesiones que causen incapacidad debería realizarse curetaje y enucleación asociado.

\section{Bibliografía}

1. Harrison's. Principios de Medicina Interna. Madrid. Ed Interamericana McGrawHill 13a Ed. 1994.

2. Fernandez-Bustillo AJ, Martin Gorvea R, Murillo Cortes J. Tumor pardo de localización maxilar: Elemento diagnóstico de hiperparatiroidismo primario. Med Oral 2000;5:208-13.

3. Goaz PW, White SC. Radiología Oral. Principios e Interpretación. 3a Ed, 1995.

4. Stafne EC. Diagnóstico Radiológico en Odontología. 5aㅡ Ed. Buenos Aires: Ed Médica Panamericana S.A, 1987; p.p.271-2.

5. Dilip K, Sushil K, Amit A. Brown tumor of the palate and mandible in association with primary hyperparathyroidism. J Oral Maxillofac Surg 2001;59:1352-4.

6. Soin AS, Gupta S, Kochupillai N, y cols. Primary hyperparathyroidism an Indian Study. Indian / Cancer 1994;31:72-7.

7. Suarez Cunqueiro MM, Schoen R, Kersten A, Klisch J, Schmelzeisen R. Brown tumor of the mandible as first manifestation of atypical parathyroid adenoma. J Oral Maxillofac Surg 2004;62:1024-8.

8. Silverman S, Ware WH, Gillooly C. Dental aspects of hyperparathyroidism. Oral Surg Oral Med Oral Pathol 1968;26:184-8.

9. Daniels JS. Primary hyperparathyroidism presenting as a palatal brown tumor. Oral Surg Oral Med Oral Pathol Oral Radiol Endod 2004;98:409-13.

10. Slem G, Varinli S, Koker F. Brown tumor of the orbit. Ann Ophtalmol 1983;15:8112.

11. Yamazaki H, Ota Y, Aoki T, Karakida K. Brown tumor of the maxilla and mandible: progressive mandibular brown tumor after removal of parathyroid adenoma. J Oral Maxillofac Surg 2003;6:719-22.

12. Scott SN, Grahan SM, Sato Y, Robinson RA. Brown tumor of the palate in a patient with primary hyperparathyroidism. Ann Otol Rhinol Laryngol 1999;108:914.

13. Merz MN, Massich DD, Marsh W, Schuller DE. Hyperparathyroidism presenting as brown tumor of the maxilla. Am J Otolaryngol 2002;23:173-6.

14. Udelsman R: Primary hyperparathyroidism. Curr Treat Options 2001;2:365-72.

15. Keyser JS, Postman GN. Brown tumor of the mandible. Am J Otolaryngol 1996; 17:407-10.

16. Emin AH, Suoglu Y, Demir D. Normocalcemic hyperparathyroidism presented with mandibular brown tumor: report of a case. Auris Nasus Larynx 2004;31:299304.

17. Fernández-Sanromán J, Antón I, Costas A. Brown tumor of the mandible as first manifestation of primary hyperparathyroidism: diagnosis and treatment. Med Oral Patol Oral Cir Bucal 2005;10:169-72.

18. Scott SN, Graham SM, Sato Y, y cols. Brown tumor of the palate in a patient with primary hyperparathyroidism. Ann Otol Rhinol Laringol 1999;108:91-4.

19. Parrish CM, O’Day DM: Brown tumor of the orbit. Arch Ophthalmol 1986;104: 1199-202.

20. Martínez Gavidia EM, Bagan JV, Milian-Masahet MA, y cols. Highly aggressive brown tumor of the maxilla as first manifestation of primary hyperparathyroidism. Int J Oral Maxillofac Surg 2000;29:447-9. of a parathyroidectomy, surgical treatment was decided on (enucleation and curettage) in October 2004 with the patient currently being asymptomatic.

\section{Conclusions}

Due to there currently being an improvement in analytical techniques, the diagnosis of hyperparathyroidism is carried out when the disease is in an asymptomatic phase, although finding patients with advanced bone lesions still exists. In all giant cell lesions the existence of primary hyperparathyroidism should be ruled out.

The treatment of first choice for bone lesions is a parathyroidectomy; however in larger lesions, or in those that are persistently growing in spite of treatment or if the lesions is causing incapacity, curettage and associated enucleation should be carried out 